\title{
A DIGITALIZÁCIÓ ÉS A MUNKA VILÁGA. MI VÁRHATÓ A ROBOTFORRADALOM UTÁN?
}

\section{BEYOND THE ROBOT REVOLUTION: DIGITALISATION AND THE WORLD OF WORK}

\author{
Andor László \\ a közgazdaságtudomány kandidátusa, tanszékvezető egyetemi docens \\ Budapesti Corvinus Egyetem \\ laszlo.andor@uni-corvinus.hu
}

\begin{abstract}
ÖSSZEFOGLALÁS
Különféle elörejelzések forognak arról, hogy milyen módon és mértékben formálja át a munkaerőpiacot és a társadalmat a digitalizációs és automatizációs forradalom. Egyének, gazdasági szereplők és kormányok szintjén egyaránt megjelenik az alkalmazkodás kényszere, ugyanakkor társadalmi igény a technológiai változások ellenőrzés alatt tartása is. A témával foglalkozó nemzetközi intézmények, így az Európai Unió is elsősorban a releváns készségek és szaktudás fejlesztését segítő stratégiákat ajánlanak. Ezzel együtt is a korábbiaknál nehezebb feladatnak látszik összehangolni a gazdasági verseny által megkövetelt rugalmasságot a foglalkoztatás stabilitásával és a munkahelyek minőségével, illetőleg a technika lehetőségeinek kiaknázását a minőségi munkahelyek és a társadalmi kohézió fenntartásának igényével.
\end{abstract}

\section{ABSTRACT}

Forecasts about the likely impact of digitalisation and automation on the labour market and society differ widely. The need for adaptation appears at the level of individuals, economic actors as well as governments, while society expects technological changes to be kept under control. International organisations dealing with these issues, including the European Union, primarily focus on strategies developing relevant skills. Nevertheless, the reconciliation of flexibility required by economic competition and the stability of employment appears to be harder than in the past, and the same can be said about the simultaneous pursuit of full exploitation of technological possibilities and the maintenance of quality jobs and social cohesion.

Kulcsszavak: digitalizáció, automatizáció, robotok, mesterséges intelligencia, a munka jövője, foglalkoztatáspolitika, humántőke

Keywords: digitalisation, automation, robots, artificial intelligence, future of work, employment policy, human capital 
Az elmúlt két-három évben temérdek elemzés - és találgatás - látott napvilágot arról, hogy milyen mértékben alakítja át életünket a legújabb technikai forradalom: a digitalizáció, automatizáció és robotizáció, és az ezek nyomán kibontakozó, ún. 4.0-s ipari forradalom. Az alábbiakban áttekintjük a vonatkozó irodalom egy részét, különösképpen azzal kapcsolatban, hogy vajon milyen mértékü, iramú, horderejű gazdasági-társadalmi átalakulásról beszélünk, és a különböző nemzetközi intézmények (Európai Unió, OECD, ILO) milyen gazdasági és társadalmi stratégiákat ajánlanak tagországaiknak.

\section{AZ ELŐREJELZÉSEK BIZONYTALANSÁGA}

Az ezredforduló időszakában a technikai fejlődés, konkrétan a digitalizáció és az általa életre hívott infokommunikáció többnyire pozitív érzéseket és várakozásokat keltett a gazdasági teljesítményre, az életminőségre és a munkalehetőségre gyakorolt hatás tekintetében egyaránt. Érezhető, mérhető volt, hogy „erre megy a világ", nőni fog a digitalizált munkahelyek száma, s így az infokommunikációs technológiához (information and communications technology, ICT) értö munkaerő iránti kereslet. A nagy (2008-2009-es) világgazdasági válság időszakában a digitális korszakváltás a fejlett európai országok körében kitörési pontként körvonalazódott.

Az Európai Unió 2010-ben elindította az Európa 2020 nevü gazdaság- és társadalomfejlesztési stratégiát, amelynek céljaként az intelligens, fenntartható és inkluzív növekedést jelölte meg. A stratégia egyik „zászlóshajója” a digitális napirend volt, és e program jegyében indult el 2013-ban az európai „Nagykoalíció a digitális munkahelyekért" (Grand Coalition for Digital Jobs) nevü kezdeményezés. ${ }^{1}$ Egyidejűleg a Bizottság Startup Europe néven programot indított az internetes vállalkozások segítésére. Az ilyen együttműködések - a tudás- és tapasztalatcserén túl - azt a célt szolgálják, hogy az uniós politika formálására, az erőforrások mozgósítására az érdekelt felek nagyobb hatást tudjanak gyakorolni.

Idővel azonban az eufóriát felváltotta a pánik. A küszöbön álló „a nagy változáshoz" füződő várakozások azonban ma sokszor ellentétes előjelüek. Ha nem is világvége, de „munkavége” hangulat uralkodott el. ${ }^{2}$ A becslések inkább arra irányulnak, hogy vajon hány munkahelyet vesznek el tőlünk a gépek. Kiből lesz hosszabb-rövidebb időre munkanélküli? (Ford, 2016) A robotok elterjedésétől

\footnotetext{
${ }^{1}$ A kezdeményezés a hivatalos dokumentumok mellett megismerhető a sajtó tudósításaiból is (lásd URL1).

${ }^{2}$ Az új „,gépkorszakot” leíró művek között klasszikusnak számít Erik Brynjolfsson és Andrew McAfee (2016), valamint a kritikai irodalom érdekes példája Nick Srnicek és Alex Williams (2015) müve.
} 
való félelem kialakulásában nagy szerepet játszott egy oxfordi szerzőpáros: Carl Benedikt Frey és Michael Osborne, akik egy 2013-as tanulmányukban az amerikai munkahelyek 47 százalékát jósolták komputerizálhatónak (Frey-Osborne, 2013). Ha ez igaz, és néhány évtized múlva fele annyi munkahely lesz, mint most, az valóban drámai változást okoz.

A robotvita állásfoglalásra késztetett olyan jelentős nemzetközi szervezeteket, mint az ILO (International Labour Organization, Nemzetközi Munkaügyi Szervezet) és az OECD (Organisation for Economic Co-operation and Development, Gazdasági Együttmúködési és Fejlesztési Szervezet). Utóbbi egy huszonegy ország helyzetét feldolgozó nagy tanulmányban (OECD, 2016) kilenc százalékra teszi azoknak a munkahelyeknek a részarányát, amelyek automatizálhatók, tehát higgadtabban, óvatosabban szól a kihívásokról és a veszélyekröl, mint több korábbi szerző. Igaz, az OECD szakértői hozzáteszik: az állások további egynegyedét alaposan átformálja a digitális forradalom, és a maradékot is érinti valamilyen formában. ${ }^{3}$

Mind az OECD, mind pedig az ILO felhívja a figyelmet arra, hogy az automatizáció nem egyszerủen megtörténik velünk, hanem irányítható, szabályozható folyamat. Ha a cégeknek, munkáltatóknak megtakarítást jelent, akkor ki fogják váltani az élőmunkát a gépekkel. De a folyamat sebességét, feltételeit befolyásolhatja az állami szabályozás és az érintettekkel folytatott társadalmi vita, a közös innováció lehetősége (Pennel, 2015). Az alkalmazkodási és szabályozási stratégiáknak pedig tekintetbe kell venniük az egyidejüleg lezajló, ám a gazdaságot és a munka világát szintén alapjaiban érintő nagy változásokat, „megatrendeket”.

\section{PÁRHUZAMOS MEGATRENDEK}

A digitális (akkori szóhasználattal: mikroelektronikai) forradalom mint megatrend nem most kerül a szakirodalom - és a szélesebb körü társadalmi érdeklődés - fókuszába. Az 1970-es évek óta követi a tudomány mindazokat a technológiai változásokat, amelyek a mikroelektronika áttörése és a tömeges számítógépesítés nyomán egyrészt egyfajta termelékenységi forradalmat, másrészt viszont - időről időre - a nagyarányú munkahelyvesztéstől való félelmet okoztak. ${ }^{4}$

A munkahelyek számát, illetve eloszlását ugyanakkor nemcsak a technológia, hanem a nemzetközi munkamegosztás alakulása is jelentősen befolyásolja. Ezzel a kérdéssel a - szintén egyfajta megatrendnek tekintett - globalizáció szakirodal-

3 Ezek a kutatási eredmények inputot jelentenek az OECD új, 2018-ban elfogadandó Foglalkoztatási Stratégiája (Jobs Strategy) számára.

${ }^{4}$ A Római Klub egyik jelentése (Friedrichs-Schaff, 1984) ezeket az ellentmondásokat járta körül. Theodore Roszak (1990) a számítógépesítés és az informatika társadalmi ellentmondásaira, „gyermekbetegségeire" hívta fel a figyelmet. 
ma foglalkozik. A robotizáció miatti általános aggodalom hasonlít ahhoz, amikor tíz-húsz évvel ezelött egy hasonló félelem söpört végig a munkaeröpiacokon, mégpedig az, hogy sok-sok millió munkahely egyszerüen Kínába vándorolhat. Azóta nemcsak Kínába, de Indonéziába, Vietnamba és máshová is vándorolhatnak a fejlett országokból feldolgozóipari munkahelyek. A két hullám hasonlít anynyiban, hogy egy-egy nagy átalakulást jelent, amely veszélyezteti a foglalkoztatás stabilitását Európában is. Különbség az, hogy míg az új nemzetközi munkamegosztás a globalizáció időszakában inkább a közepes képzettséget igénylő, föleg ipari munkahelyeket vitte el, most az alacsony képzettséget igénylö, szolgáltató és kisegítő munkahelyek kerültek a célkeresztbe. Ugyanakkor itt kopogtat az ajtón a „mesterséges intelligencia”, vagyis a bonyolultabb, kreatívabb tevékenységek és szakmák robotok általi kiszorítása is (Susskind, R.-Susskind, D., 2015).

Mindkét említett hullámra igaz, hogy a fejlettebb országoknak érdemes humántőke-beruházással válaszolni a kihívásra. Az oktatás, képzés megfelelő reformja az egyik fontos terület, ahol a kormányzás reagálhat a technológiai változásokra. Azok az országok, amelyek Európában ezt az utat járják (például: Hollandia, Svédország), élen járnak a technikai innovációban, de meg tudják őrizni a magas szintü foglalkoztatást és a szociális kohéziót is.

Egy harmadik „megatrend” a demográfiai változás, még pontosabban az európai társadalom idősödése. Európában megkezdődött az a korszak, amikor évről évre többen lépnek ki a munkaerôpiacról (nyugállományba), mint ahányan belépnek oda. Ezt a trendet az Európán kívülről jövő bevándorlás csak igen kis mértékben enyhíti, az Európán belüli migráció viszont számos ország esetében súlyosbítja (főként az unió keleti peremvidékén).

\section{ALKALMAZKODÁSI STRATÉGIÁK}

Az Európai Bizottság központi agytrösztje 2016 júniusában stratégiai elemzést adott közre a munka jövőjéről (EPSC, 2016). Ennek középpontjába a szaktudást és a készségek fejlesztését állította. A megközelítés kiszámítható volt; az EU válasza beágyazódik abba a két évtizedes trendbe, amely a magasabb szintű foglalkoztatásra törekvés jegyében az emberi tőke fejlesztését, a munkaerő versenyképességét célozza, és ennek érdekében a tagországokban a felsőoktatásban részt vevők számának bővítését ${ }^{5}$, valamint a szakképzés előremutató reformját szorgalmazza.

\footnotetext{
${ }^{5}$ A felsőoktatásban részt vevők számának bővítése hosszabb ideje az uniós politika céljai között szerepel. Ez a törekvés eredményesnek tekinthető, amennyiben a felsőoktatási diplomával rendelkezők aránya a 2000-es 22 százalékról 2020-ra várhatóan 37 százalékra emelkedik (miközben a csak alapfokú végzettséggel rendelkezők aránya 31 százalékról 16 százalékra csökken (EPSC, 2016, 5.).
} 
Az elmúlt két évtizedben az EU tagországaiban jelentősen nőtt a felsőoktatásban részt vevők száma, illetőleg csökkent a munkaerőn belül a csak alapfokú képzettséggel rendelkezők részaránya. Elörelépés történt a korai iskolaelhagyás visszaszorításában is. Önmagában azonban a felsőoktatásban részt vevők számának bővítése nem ad kielégítő megoldást, ha közben nem változik a tartalom; törekedni kell arra is, hogy az iskolások minél több „horizontális készséget” sajátítsanak el (érzelmi intelligencia, gazdálkodás, kommunikáció stb.).

A technikai korszakváltás azonban nemcsak a foglalkoztatás szintjének fenntarthatóságát kérdőjelezi meg, hanem a korábban kialakult szociális modellek jövőjét is. Az Európai Unió intézményei emiatt intenzíven foglalkoznak azzal a kérdéssel is, hogy a digitális forradalom nyomán megváltozott munkaszervezési és foglalkoztatási módok hogyan hatnak ki a szociális jogokra, mindenekelött a társadalombiztosításra. Az Európai Parlament ún. szociális pillérhez kapcsolódó jelentésében (2016. december) felkérte az Európai Bizottságot, hogy hangolja össze az új foglalkoztatási formákat a társadalombiztosítás és a jóléti rendszer Európában kialakult modelljeivel, és erre nyújtson be jogszabálytervezetet. $^{6}$

Értelemszerűen az ILO is a társadalmi igazságosság előmozdítása (egyenlőtlenségekre, munkakörülményekre gyakorolt hatás) szempontjából tanulmányozza a kérdést elsősorban. ${ }^{7}$ Mind az EU, mind az ILO számára fontos szempont továbbá a munkakörülmények alakulása az újabb technikai változások függvényében (például: rugalmas foglalkoztatási formák, munka és magánélet összehangolásának lehetősége, munkavédelem fejlődése).

A technológiai korszakváltásból fakadó munkahelyvesztést sokan úgy látják kezelhetőnek, megszelídíthetőnek, hogy egy fundamentális szociális reformmal, és egészen konkrétan a feltétel nélküli, állampolgári alapjövedelem (FNA) bevezetésével kapcsolnák össze. Az FNA-ról sok vita zajlott és zajlik, de politikai értelemben eddig kevés helyen tört át, a robotizáció hatásairól szóló vita sokak számára most érdekessé teszi.

Más irányban keresi a megszelídítés lehetőségét a Richard Freeman (2015). A harvardi professzor úgy látja, hogy ez a folyamat végeredményben javíthatja is a dolgozók anyagi jólétét, tehát a javuló termelékenység magasabb jövedelemhez és több szabadidőhöz is vezethet. Ehhez az kell, hogy a munkavállalók részesedjenek a tőkéből; résztulajdonossá, a mainál sokkal nagyobb arányban részvényessé is vál-

${ }^{6}$ Figyelemre méltó, hogy az „új típusú” foglalkoztatásban részt vevők szociális védelméről az EU-ból távozni készülő Egyesült Királyság kormánya nyújtott be tervezetet 2017 júliusában (Cowburn, 2017).

${ }^{7}$ Lásd erről Guy Ryder (2015). Az ILO főigazgatója a szervezet kutatásainak fókuszába állította a munka jövőjének kérdését, amiről rendszeresen tartanak konferenciákat Genfben és más helyszíneken. 
janak. Úgy fogalmaz: „Résztulajdon nélkül a dolgozók a robotok urainak dolgozó szolgák lesznek." A gépromboló, technikai újításokat korlátozó reflex szinte mindig előjön a nagy válságok és változások idején. Az elöremutató megoldások azonban nem ebböl születtek, hanem a technikai és társadalmi innováció összekapcsolásából, a társadalmi értékeket és igényeket tekintetbe vevő szabályozásból.

\section{MAGYAR VONATKOZÁSOK}

A digitalizáció és automatizáció társadalmi hatásaira Magyarországon is találunk számos példát, beleértve a munkahelyvesztéssel kapcsolatos várakozásokat. Például, aki manapság metrót használ Budapesten, belépéskor ellenőrökkel találkozik. Ha minden igaz, másfél év múlva ezek a dolgozók befejezik majd ezt a tevékenységet. Valami mást fognak csinálni, mert nálunk is megvalósul az elektronikus jegyrendszer, amely a világ (és benne Európa) számos nagyvárosában a hétköznapi élet magától értetődő részét képezi.

Ez csak egyetlen, hozzánk közeli és mindenki által ismert példa arra, hogy a gazdaság korszerüsödése jegyében a technika kiszorítja az élőmunkát. Ugyanakkor a hazai folyamatok vizsgálatánál is fontos, hogy ne essünk az aránytévesztés csapdájába. Magyarország - és sok más ország - esetében nem mondhatjuk, hogy a nagyarányú munkanélküliséggel és inaktivátással jellemezhető vidékeken ezeket a problémákat közvetlenül és elsődlegesen a technológiai tényezők okoznák.

A külgazdasági, demográfiai és technológiai változások egyidejüsége miatt mondhatjuk, hogy a mai hazai munkaerőpiaci folyamatok újszerủek, komplex elemzést és kormányzati válaszokat igényelnek. A magyar társadalmat folyamatos idősödés jellemzi, amely az elmúlt évek jelentős elvándorlásával párosulva jelentősen befolyásolja a hosszú távú munkaerö-kínálatot. Ugyanakkor egyes (föleg a keleti) régiókban továbbra is fennáll a magas szintủ inaktivitás, öszszefüggésben a rendszerváltás elhúzódó hatásaival és a cigányság halmozottan hátrányos helyzetével.

Magyarország az Európa 2020 stratégia jegyében ambiciózus célt tüzött ki a foglalkoztatási ráta 75\%-ra emelésével (a 20-64 éves korosztályban). A 2009-es nagy válság utáni időszakban a közfoglalkoztatás vált az állami foglalkoztatáspolitika domináns elemévé. Ennek felülvizsgálata - a munkaerőhiánnyal öszszefüggésben - megkezdődött, és még inkább aktuálissá válik a munka jövőjére vonatkozó új elképzelések tekintetbevételével. A fenntarthatóság egyik fö pillére inkább a szakképzés (készségek elsajátítása az iskolarendszerben), illetőleg az élethosszig tartó tanulás intézményeinek kiépítése, ahhoz való hozzáférés alakulása kellene, hogy legyen.

$\mathrm{Az}$ iskolarendszerben a legutóbbi években végrehajtott szerkezeti változások azonban nem segítik a szembenézést az új technológiai forradalom kihívásaival. 
A tanköteles kor leszállítása, a szegregáció felé mutató trendek elfogadása, az idegen nyelvek oktatása terén mutatkozó stagnálás mind arról szólnak, hogy Magyarország egyre rosszabb pozícióba kerülhet a nemzetközi gazdasági versenyben. Mindez pedig a társadalmi kohézió szempontjából is veszélyes jelenségeknek ágyazhat meg.

Magyarországon is számolni kell tehát a munkaerőpiac átalakulásával, ám a digitalizáció és automatizáció hatásainak felmérése csak most kezdődik. ${ }^{8} \mathrm{Az}$ ILO és az OECD keretein belül zajló elemző munka, valamint a szociális pillér keretében folyó uniós vita és jogszabályalkotás Magyarország számára is fontos terepet kínál a jövő formálásához. Közben érdemes figyelni olyan mintákra, mint Észtországé. Ez a példa jól mutatja, hogy a terv- és piacgazdaság közötti átmenetet nemrég véghezvivő országok nincsenek predesztinálva az olcsó munkaerő versenyképességére építő, összeszerelö üzemekre szakosodó gazdasági övezet szerepére.

\section{KÖVETKEZTETÉS}

A hullámokban jelentkező technológiai forradalmak kihívást jelentenek mind a gazdaság, mind a társadalom kialakult rendje számára. A jelenlegi robotizációs hullám, valamint az áttörés a mesterséges intelligencia felé ilyen hullámnak tekinthető. Nemzetközi szervezetekben - EU-keretek között is - folyamatosan zajlik e változások jellegének, sebességének és hatásainak felmérése. Egyének, gazdasági és politikai szereplők számára fontos kérdés az ,alkalmazkodás”, ugyanakkor egyértelmü társadalmi igény mutatkozik e technológiai változások ellenőrzés alatt tartására, illetőleg arra, hogy a technika lehetőségeit összehangoljuk a minőségi munkahelyek és a társadalmi kohézió fenntartásának igényével. Az Európai Unió elsősorban a releváns készségek és szaktudás fejlesztésére koncentrál, és igyekszik összehangolni a gazdasági verseny által igényelt rugalmasságot a foglalkoztatás stabilitásával és a munkahelyek minőségével. Magyarországnak elsősorban több és az európai trendekhez jobban igazodó humántőke-beruházással kellene válaszolnia a „munka jövőjével” összefüggő kihívásokra.

Jelen publikáció az Európai Unió, Magyarország és az Európai Szociális Alap társfinanszírozása által biztosított forrásból az EFOP-3.6.2-16-2017-00017 azonosítójú „Fenntartható, intelligens és befogadó regionális és városi modellek” címü projekt keretében jött létre.

\footnotetext{
${ }^{8}$ A kevés számú, összefoglaló jellegủ mü közül említést érdemel Forgács Imre (2015), valamint Ohnsorge Szabó László (2008) tanulmánya.
} 


\section{IRODALOM}

Brynjolfsson, E. - McAfee, A. (2016): The Second Machine Age: Work, Progress, and Prosperity in a Time of Brilliant Technologies. Norton

Cowburn, A. (2017): Matthew Taylor Review into Workers' Rights 'Recommends Employers Must Prove They Can Pay above the Minimum Wage'. The Independent, 10 July 2017. https:/goo.gl/ TrXKXd

EPSC - European Commission (2016): The Future of Work: Skills and Resilience for a World of Change. EPSC Strategic Notes, Issue 13. http://ec.europa.eu/epsc/publications/strategic-notes/ future-work_en

Ford, M. (2016): The Rise of the Robots. Technology and the Threat of Mass Unemployment. London: Oneworld

Forgács I. (2015): Az eltünö munka nyomában - A Big Data és a pénztőke évszázada. Budapest: Gondolat Kiadó

Freeman, R. (2015): The future of work: who owns the robot in your future work life? Pacific Standard, 17 August 2015. https://psmag.com/economics/the-future-of-work-who-owns-therobot-in-your-future-work-life

Frey, C. B. - Osborne, M. (2013): The Future of Employment: How Susceptible are Jobs to Computerisation. Oxford Martin Programme on Technology and Employment. Oxford: Oxford Martin School at the University of Oxford, http://www.oxfordmartin.ox.ac.uk/downloads/academic/ The_Future_of_Employment.pdf

Friedrichs, G. - Schaff, A. (1984): Mikroelektronika és társadalom: Áldás vagy átok. (Mikroelektronika és társadalom sorozat). Budapest: Statisztikai Kiadó

OECD (2016): Automation and Independent Work in a Digital Economy. Policy Brief on the Future of Work. Paris: OECD Publishing, http://www.oecd.org/employment/future-of-work.htm https://www.oecd.org/els/emp/Policy\%20brief\%20-\%20Automation\%20and\%20Independent $\% 20$ Work $\% 20$ in $\% 20 \mathrm{a} \% 20$ Digital\%20Economy.pdf

Ohnsorge Szabó L. (2008): A munka vége? Nemzeti Érdek, II, 4.

Pennel, D. (2015): The Ego Revolution at Work. Paris: Works That Work, http://www.wecglobal. org/fileadmin/templates/ciett/docs/The_Ego_Revolution_At_Work_by_Denis_Pennel_-_ book_format_A5_final.pdf

Roszak, T. (1990): Az információ kultusza, avagy a számitógépek folklórja és a gondolkodás igazi müvészete. (ford. Gieler Gy.) Budapest: Európa Könyvkiadó

Ryder, G. (2015): Anticipating the Future of Work Essential for Advancing Social Justice. 13 June 2015. http://www.ilo.org/ilc/ILCSessions/104/WCMS_375766/lang--en/index.htm

Srnicek, N. - Williams, A. (2015): Inventing the Future. Post-Capitalism and the World of Work. London: Verso

Susskind, R. - Susskind, D. (2015): The Future of Professions. How Technology will Transform the Work of Human Experts. Oxford University Press

URL1: https://www.timesofmalta.com/articles/view/20130314/technology/Grand-coalition-for-digital-jobs-in-the-EU.461478 